\title{
Grundtvig og kvækerne
}

\author{
Jes Fabricius Møller
}

Niels Kjær (2016), Grundtvig og kvakerne, Books on Demand, 56 sider, 120 kr.

Cand.theol. Niels Kjær samler i denne lille bog det meste af den tilgængelige viden om Grundtvigs forhold til kvækerne. Undersøgelsen er ganske vist ikke komplet. Kjær ville ved at konsultere Borup og Schrøders håndbog i N.F.S. Grundtvigs skrifter have fundet et par flere steder, hvor Grundtvig omtaler kvækerne. Det er vel at mærke kun de britiske og amerikanske kvækere, der er tale om. De norske (efter 1814) og de tyske lod Grundtvig ude af betragtning. Med tiden vil grundtvigsværker.dk også blive en stor hjælp for studier af denne karakter. Men de store linjer er antagelig tegnet tilfredsstillende op med Kjærs arbejde.

Bogen bygger væsentligst på Bjørn Kornerups artikel "To Kvæker-Besøg i Danmark i det 19. århundrede" i Kirkehistoriske Samlinger 1951, Ole Vinds disputats om Grundtvigs historiefilosofi og K.E. Bugges bog om Grundtvig og slavesagen fra 2003. Kjær tager udgangspunkt i, at der er ligheder mellem kvækerdommen og grundtvigianismen, samtidig med at Grundtvig hele sit liv fastholdt en afstand til kvækerne, især fordi de afviste sakramenternes betydning og "at de tilsidesætter forsoningslæren (læren om at Jesus døde på korset for at sone menneskenes synd)" (s. 9). Spørgsmålet her må dog være, om kvækerne er helt uden forsoningslære, eller om de bare abonnerer på en anden og mere subjektiv forsoningslære end Grundtvig?

Efter 1841 udviklede Grundtvig dog en sympati for bevægelsens repræsentanter, herunder ikke mindst Elizabeth Fry, hvem han netop havde mødt under hendes besøg i Danmark, og for bevægelsens sag. Især i spørgsmålet om religionsfrihed var der sammenfald mellem Grundtvigs og kvækernes synspunkter. Her bruger Kjær Ole Vinds påvisning af, at Grundtvig netop hos kvækerne fandt en opløsning af det af ham identificerede paradoks, at hvor der var ånd, var der ingen frihed, og hvor der var frihed, var der ingen ånd (s. 38). Også George Fox, som Grundtvig tidligere havde kaldt en "hovmodig Sværmer" - en meget voldsom kritik 
i en erklæret lutheraners mund - blev nu beskrevet mere positivt. Kjær mener endda, at det er mødet med kvækerne, der bidrog til, "at Grundtvig i den resterende del af sit liv i stadig stigende grad engagerer sig i en række folkelige anliggender, herunder i politisk virksomhed.” (s. 36). Det er en dristig konklusion, der dog ikke kan afvises helt. Identifikationen af Grundtvigs og grundtvigianismens affinitet for kvækerne og vice versa kan Kjær bygge videre på, idet han peger på, at de kvækere, der i dag fastholder medlemskabet af den danske folkekirke, føler sig tættest beslægtede med grundtvigianerne.

Kjær viser både den afstand og den nærhed, der fandtes og findes i forholdet mellem Grundtvig og grundtvigianismen på den ene side og George Fox og kvækerne på den anden. Han konkluderer selv til afslutning, "at grundtvigianismen og kvækerdommen historisk set er beslægtede trosretninger, der gennem dialog og konfrontation supplerer og kompletterer hinanden.” (s. 56). Det føjer sig til den fiffige iagttagelse af Kjær, at de bredskyggede såkaldte grundtvigianerhatte ligner dem, som kendes fra portrætter af George Fox. 